\title{
"Money was the Problem": Financial Difficulty is the Main Reason for Treatment Abandonment by Children with Cancer in South West Uganda
}

\author{
Barnabas Atwiine ${ }^{1}$, Imelda Busingye ${ }^{2}$, Rose Kyarisiima ${ }^{2}$, Emmanuel Baluku², Ruth \\ Mbabazi $^{2}$, Brian Bamwine ${ }^{2}$, Siyadora Ankunda ${ }^{2}$, Jaime Libes ${ }^{3}$, Howard Weinstein ${ }^{4}$, Kevin \\ Schwartz $^{4}$, and Gertrude Kiwanuka ${ }^{1}$ \\ ${ }^{1}$ Mbarara University of Science and Technology \\ ${ }^{2}$ Mbarara National Referral Hospital \\ ${ }^{3}$ University of Illinois College of Medicine \\ ${ }^{4}$ Massachusetts General Hospital
}

April 16, 2021

\begin{abstract}
Introduction - Treatment abandonment contributes significantly to poor survival of children with cancer in low-middle-income countries (LMICs). In order to inform an approach to this problem at our Cancer Unit, we investigated why caregivers withdraw their children from treatment. Methods - In a qualitative study, in-depth interviews were conducted with caregivers of children who had abandoned cancer treatment at the Paediatric Cancer Unit (PCU) of Mbarara Regional Referral Hospital (MRRH) in South Western Uganda, between May 2017 and September 2020. Recorded in-depth interviews with caregivers were transcribed and analyzed to identify themes of caregiver self-reported reasons for treatment abandonment. Results - Seventy-seven out of $343(22.4 \%)$ children treated for cancer at MRRH abandoned treatment during the study period; 20 contactable and consenting caregivers participated in the study. The median age of children's caregivers was 37 years and most (65\%) were mothers. At the time of this study, eight $(40 \%)$ children were alive and $5(62.5 \%)$ were males; with a median age of 6.5 years. Financial difficulties, other obligations, the child falsely appearing cured, preference for alternative treatments, belief that cancer was incurable, fear that the child's death was imminent and chemotherapy side-effects were the caregivers' reasons for treatment abandonment. Conclusions and Recommendation - Treatment abandonment among children with cancer in Uganda is, most times, as a result of difficult conditions beyond the caregivers' control and needs to be approached with empathy and support.
\end{abstract}

\section{Hosted file}

Treatment abandonment manuscript submission.pdf available at https://authorea.com/users/ 395452/articles/518330--money-was-the-problem-financial-difficulty-is-the-main-reasonfor-treatment-abandonment-by-children-with-cancer-in-south-west-uganda

\section{Hosted file}

treatment abandonment figure 1.pdf available at https://authorea.com/users/395452/articles/ 518330--money-was-the-problem-financial-difficulty-is-the-main-reason-for-treatmentabandonment-by-children-with-cancer-in-south-west-uganda

\section{Hosted file}

Table 1 Caregiver Demographic Characteristics.pdf available at https://authorea.com/users/ 395452/articles/518330--money-was-the-problem-financial-difficulty-is-the-main-reason- 
for-treatment-abandonment-by-children-with-cancer-in-south-west-uganda

\section{Hosted file}

Table 2 Demographic and Clinical Characteristics of Children with Treatment Abandonment Still Alive.pdf available at https://authorea.com/users/395452/articles/518330--money-was-the-problemfinancial-difficulty-is-the-main-reason-for-treatment-abandonment-by-children-withcancer-in-south-west-uganda

\section{Hosted file}

Table 3 Summary of Caregiver Reasons for Treatment Abandonment.pdf available at https: //authorea.com/users/395452/articles/518330--money-was-the-problem-financial-difficultyis-the-main-reason-for-treatment-abandonment-by-children-with-cancer-in-south-westuganda 